\title{
Efficiency of Nanoparticles Dietary Supplement on The Growth Performance of Nile Tilapia "Oreochromis Niloticus" Intoxicated With Aflatoxin B1.
}

\author{
Nesma Mohamed. Abdel-Aliem. Moghieth ${ }^{a}$, Adel A. Shaheen ${ }^{b}$, and Ahmed S. M. S. ${ }^{\text {. }}$ \\ ${ }^{\text {a }}$ Department of Food Toxicology and Contaminants, National Research Center, Cairo, Egypt. \\ ${ }^{b}$ Department of Aquatic animal disease and management, Faculty of Vet medicine, Benha University, Egypt. \\ ${ }^{\mathrm{c}}$ Department of Animal Production, Faculty of Agriculture, Benha University, Egypt. \\ Corresponding author: shaheen_aa@yahoo.com
}

\begin{abstract}
The examined fish intoxicated with aflatoxin $\mathrm{B}_{1}\left(\mathrm{AFB}_{1}\right)$ showed several non-specific signs, including inadequate growth, significant losses in aquaculture industry especially resulting from aflatoxicosis. The study using Zinc oxide $(\mathrm{ZnO})$ and Hematite $\left(\alpha-\mathrm{Fe}_{2} \mathrm{O}_{3}\right)$ nanoparticles (NPs) to assess the effect of using as on their own negative impacts of $\mathrm{AFB}_{1} 3 \mathrm{ppm} / \mathrm{Kg}$ for 13 weeks was studied 360 healthy fingerlings of Nile tilapia, were divided into eight groups (15 fish/ group) with three replicates, it has been applied in 24 aquariums. Group ${ }_{1}\left(\mathrm{G}_{1}\right)$ fed only a basal diet as control. While, $\mathrm{G}_{2}, \mathrm{G}_{3}$, and $\mathrm{G}_{4}$ were fed on diets supplemented with $2 \mathrm{~g} / \mathrm{kg}$ diet of $\mathrm{ZnO}$ NPs, Hematite NPs and combination of both respectively. Group ${ }_{5}\left(\mathrm{G}_{5}\right)$ was fed on diets contamination with $\operatorname{AFB}_{1}\left(3 \mathrm{ppm} / \mathrm{kg}\right.$ diet), while $\mathrm{G}_{6}, \mathrm{G}_{7}$ and $\mathrm{G}_{8}$ were fed on diets containing $2 \mathrm{~g} / \mathrm{kg}$ diet of (ZnO NPs, Hematite NPs and combination of both) plus $\mathrm{AFB}_{1}(3 \mathrm{ppm} / \mathrm{kg}$ diet) respectively.

Experimental treatments affected significantly on the Final Body Weight (FBW), Daily Gain (DG), Feed Conversion Ratio (FCR) and mortality Table $(1,2)$. FBW and DG reduced to $37.856 \mathrm{~g}$ and $0.227 \mathrm{~g}$ in fish feed containing $\mathrm{AFB}_{1}$, when compared with groups $\mathrm{AFB}_{1}$ which supported with feed additives (ZnO, Hematite and combination of both) NPs, which reported final body weight 45.507, 47.007, $49.762 \mathrm{~g}$ and daily gain 0.313 , $0.328,0.360 \mathrm{~g}$ respectively. The highest FBW and DG were determined in group treated with feed additives combination of ( $\mathrm{ZnO}$ and Hematite) nanoparticles, keep it track of by the fish group fed diet supplemented with Hematite NPs then those fed diet supplemented with ZnO NPs and the recorded values were for final body weight $55.857,61.500,63.874 \mathrm{~g}$ daily gain $0.427,0.488,0.515 \mathrm{~g}$ respectively than that of the control group $\mathrm{G}_{1}$ 52.784, g FBW and $0.393 \mathrm{~g} \mathrm{DG.}$

The highest survival rate was obtained in fish group treated with combination of ( $\mathrm{ZnO}$ and Hematite) nanoparticles, The survival rate was $(95.556 \%)$ in fish fed diets combination of ( $\mathrm{ZnO}$ and Hematite) NPs, while it was $57.778 \%$ in fish group $\mathrm{G}_{5}$ fed $\mathrm{AFB}_{1}$, which enhanced in aflatoxicated group $\mathrm{G}_{8}$ which supplemented with combination of ( $\mathrm{ZnO}$ and Hematite) NPs $84.444 \%$, and in aflatoxicated group $\mathrm{G}_{7}$ which supplemented with Hematite NPs $77.778 \%$, and in aflatoxicated group $\mathrm{G}_{6}$ which supplemented with ZnO NPs $75.556 \%$.

The best FCR was obtained in same order in fish group treated with combination of ZnO NPs and Hematite NPs, Hematite NPs then ZnO NPs 1.187, 1.170, 1.253 compared to the control group which recorded 1.462. On the other hand, aflatoxicated groups significantly affected feed conversion impaired significantly affected, aflatoxicated group recorded 1.950 but when supported with ZnO NPs, Hematite NPs and combination of both recorded $1.541,1.525$ and 1.502 respectively.
\end{abstract}

Keywords: Food safety, Hematite, Mycotoxins, Nano food/ feed additives, Zinc oxide.

\section{Introduction:}

In aquaculture, the exclusive use of animalderived proteins is not sustainable, therefore; Plant ingredients had to be replaced, whose incorporation and inclusion in the feed increased the likelihood of Mycotoxins, that increase the health riskiness to animal (Santos et al., 2010; Almeida et al., 2011; Oliva-Teles et al., 2015; Daniel 2018; Lei et al., 2018).

Aflatoxins are about twenty types, A. flavus has a high ability to produce six types of aflatoxins including $(\mathrm{B}, \mathrm{G}$ and $\mathrm{M})$, but major aflatoxins are two families ( $B$ and $G$ ), in which $B$ family containing $\left(B_{1}+B_{2}\right)$, and $G$ family containing $\left(G_{1}+G_{2}\right)$ usually found together in foods and feeds in various proportions. The most dangerous, virulent poison and toxicity is aflatoxin $\mathrm{B}_{1}\left(\mathrm{AFB}_{1}\right)$ from $\mathrm{B}$ family. $\mathrm{AFB}_{1}$ contaminated diets are among the commonest causes of low production and survival rate in fish farming, the performance and physiological responses of fish with regard to $\mathrm{AFB}_{1}$ toxicity are different for each species of fish (Wu et al., 2019; Abdel-Daim et al., 2020; Benkerroum 2020).

Nile tilapia (O. niloticus) is an important cultured fish species in Egypt and one of highly sensitive fish species to $\mathrm{AFB}_{1}$ (Kenawy et al., 2009). The exposure of fish to $\mathrm{AFB}_{1}$ causes many risks such as the decrease in growth performance, increase susceptibility to disease and high mortality Santacroce et al., (2008). Nanotechnology, one of the most dynamically developing sciences, it is the main base for many innovative branches, and major opportunity for the economy and sustainable 
development, and an emerging avenue employed in disease prevention and treatment. Although the application of it in an emerging stage, it may have the potential to solve most of the problems and the obstacles in aquaculture (Umalatha et al., 2016; Thangapandiyan and Monika 2020).

Among the nanomaterial's (NMs), Zinc oxide and Hematite have garnered a wide area of attention due to their unique properties as well as safe significantly on the environment.

Hassan et al., (2014) evaluated zinc oxide nanoparticles against fungi in culture media. As for the results of the antifungal activities of Zinc oxid, molds as Aspergillus flavus and Aspergillus ochraceus needed a higher dose of Zinc oxide, compared to Aspergillus niger which required lower concentration to inhibit their growth.

Hassan et al., (2012) noted that the growth of aflatoxigenic fungi mold and the toxins they produce were prevent by supplemented of $8 \mu \mathrm{g} / \mathrm{ml}$ of Zinc oxide nanoparticles, while that of ochratoxin (OTA) and fumonisin $\mathrm{B}_{1}\left(\mathrm{FUMB}_{1}\right)$ producing molds and mycotoxins production were prevented and restricted by supplement of $10 \mu \mathrm{g} / \mathrm{ml}$ on Zinc oxide nanoparticles to examined media.

The anti-fungal potential of prepared Zinc oxide NPs and Hematite NPs were estimate against isolated aflatoxigenic and non-aflatoxigenic Aspergillus flavus that were recon quest from animal and poultry feeds associated with animal diseases using well and disc diffusion tests, the zone of A. flavus growth prevent appeared at lower concentration $50 \mu \mathrm{g} / \mathrm{ml}$ of Zinc oxide NPs and Hematite NPs, and the production of $\mathrm{AFB}_{1}$ by toxigenic strains on synthetic or natural medium was affected by all used nanoparticles (Nabawy et al., 2014).

The main target of the study is to evaluate the effect of the dietary supplementation of nanoparticles of Zinc oxide and Hematite or combination of both as trails to control aflatoxicosis $\left(\mathrm{AFB}_{1}\right)$ and to evaluate the effect of those nanoparticles in improving the growth performance of Nile tilapia.

\section{Materials and methods}

The present study was carried at Department of Aquatic animal disease and Management, Faculty of Veterinary Medicine, Benha University, Egypt. The experimental period lasted (13 Weeks) from 1/June to $1 /$ September, 2018.

\section{Fish diet}

All fish groups were fed on basal pelleted diet composed of: yellow corn $40 \%$, fish meal $16 \%$, soybean meal $28 \%$, and wheat bran $10.5 \%$. These diets were containing: crude protein (C.P) $30.18 \%$, Lipids (E.E) $4.44 \%$, crude fiber (C.F) $9.33 \%$ and metabolism energy (ME) $2610 \mathrm{Kcal} / \mathrm{Kg}$ diet.
The feeding rate was $3 \%$ of total biomass during the experimental period. Bi- weeks the feed weight changes according to the actual body weight at that time. The feed was offered for 6 day/week, Fish were fed 3 times/ day at 7.30 to $8.30 \mathrm{Am}$., then at 11:30 to $12: 30 \mathrm{pm}$., and the last meal at 3:30 to $4: 30 \mathrm{pm}$. for 13 weeks.

\section{Fish and experimental conditions:}

Healthy fingerlings of Nile tilapia (O. niloticus) obtained from the fish Hatchery of Central Laboratory for Aquaculture Research at Abbassa, Sharqia, Egypt. 360 fingerlings (weight with average $16.70 \pm 0.45 \mathrm{~g}$ / fish) after acclimation in well prepared fiber glass tanks (1000 liter, each tank was filled by 800 liter dechlorinated tap water) for two weeks under normal laboratory conditions.

Fish were randomly distributed into well prepared 24 glass aquaria $100 \times 100 \times 50 \mathrm{~cm}$ (500 liter capacity) were used in the study and each aquarium was filled by 400 liter dechlorinated tap water, representing 8 groups (three replicates/ treatment) maintained aerated continuously from storage tank. The experiment installed in an environmentally controlled laboratory, a photoperiod of twelve hour light and twelve hour darkness, and aeration by an air blower of 5 watt /aquarium.

Group $_{1}$ on a basal diet only $\left(D_{1}\right)$, while $G_{2}, G_{3}$ and $G_{4}$ treated with supplemented diets $(2 \mathrm{~g} / \mathrm{kg})(\mathrm{ZnO}$, Hematite and combination of both) fed without $\mathrm{AFB}_{1}$ $\left(D_{2}, D_{3}\right.$ and $\left.D_{4}\right)$ respectively.

$\mathrm{G}_{5}$ was fed on $\mathrm{AFB}_{1}(3 \mathrm{ppm} / \mathrm{Kg})$ contaminated $\operatorname{diet}\left(\mathrm{D}_{5}\right), \mathrm{G}_{6}, \mathrm{G}_{7}$ and $\mathrm{G}_{8}$ were fed on ( $\mathrm{ZnO}$, Hematite and combination of both) respectively supplemented diets $(2 \mathrm{~g} / \mathrm{kg})$ with $\mathrm{AFB}_{1}(3 \mathrm{ppm} / \mathrm{Kg})$.

The diet residual and fish wastes of each aquarium were collected by siphoning before the $2^{\text {ed }}$ daily feeding, each aquarium was partially cleaned including the fish feces and the water partially changed (nearly $33.33 \%$ ).

\section{Water quality}

The aquariums were supplied with de-chlorinated tap water. Aeration was continuously provided using an air blower ( 2 outlets 5 watt/ aquarium). The remaining wastes in each aquarium was removed, was changed approximately $1 / 3$ of the water in the aquarium, dissolved oxygen was maintained at above $5.9 \mathrm{mg} / \mathrm{L}$, by continuous aeration (estimated by using dissolved oxygen meter: HI 93732N HANNA, Hungary) and water temperature at $28 \pm 1{ }^{\circ} \mathrm{C}$. Ammonia concentration was $0.53 \pm 0.07 \mathrm{mg} / \mathrm{L}$ and $\mathrm{pH}$ was in range of 7-7.50 during the experiment (estimated by using $\mathrm{pH}$ meter 211, HANNA instruments, U.S.A.). Photoperiod was natural by the sunlight. 


\section{Fish weight and growth}

The average fish weight was $16.7 \pm 0.45 \mathrm{~g} / \mathrm{fish}$ at the beginning of the experiment and bi-weekly intervals throughout the experimental duration 13 weeks; Food consumed was calculated as ( $\mathrm{g} / \mathrm{fish}$ /day) by dividing the amount of food consumed each day by the number of fish in the aquarium. Weight Gain (WG), Mortality, Feed Conversion Ratio (FCR), Protein Efficiency Ratio (PER) and Specific Growth Rate (SGR), were measured according to formulae of Altunoglu et al., (2017); Elumalai et al., (2019).

\section{Statistical analysis}

Data were subjected to a one-way analysis of variance (ANOVA) followed by Duncan, (1955) using XLSTAT, (2014) to compare results obtained from treatments groups with results obtained from the control group, and differences were considered statistically significant at $p<0.05$. Values were expressed as means \pm standard error.

\section{Results and discussion}

\section{Growth performance and feed efficiency:}

Economically, aflatoxins contamination is one of the most severe problems for the livestock and feed industries (Souza et al., 2020). Nile tilapia ( $O$. niloticus) is an important cultured fish species in Egypt and one of highly sensitive fish species to $\mathrm{AFB}_{1}$ (Kenawy et al., 2009).

In our present study; it has been observed that aflatoxin has a negative impact on the growth and survival rate of the studied fish. It was found that the weight gain significantly decreased in aflatoxin treated fish as compared to the fish kept at control condition, the Highest average BW $63.874 \mathrm{~g}$ was recorded in fish under the $\mathrm{G}_{4}$ ( $\mathrm{ZnO}$ and Hematite) group, The lowest average body weight $37.856 \mathrm{~g}$ was observed in group $\mathrm{G}_{5}$. On the contrary, a similar trend was also demonstrated in specific growth rate.

The growth rate, specific growth rate was high in group $\mathrm{G}_{4}$ it reported 1.473 , but decreased to 0.868 ingroup $\mathrm{G}_{5}$ (Table1).

The mortality rate was increased in aflatoxicated dietary feed; the survival rate of different groups was significantly different. The lowest survival rate was found in aflatoxicated group $57.778 \%$, on the other hand group $\mathrm{G}_{4}$ was exhibited about $95.556 \%$ of the survival rate.

At the end of the feeding trial, Nile tilapia fingerlings fed concentrations of $3 \mathrm{ppm} \mathrm{AFB}_{1} / \mathrm{kg}$ for 13 weeks, showed significantly depressed growth rate, average weight gain and average daily gain, and mean final body weight. All these parameter was higher in treatments $(\mathrm{ZnO}$, Hematite nanoparticles and combination of both) without aflatoxins in diets, as showed in (Table 1, 2).

These findings were closely similar to those mentioned by Ayyat et al., (2018) who noted a decrease in the FBW, DG and FCR, in Nile tilapia (O. niloticus) fed a diet contaminated with two thousand $\mu \mathrm{g} / \mathrm{kg}$ feed of aflatoxin $\mathrm{B}_{1}$ compared with a control diet (without fungus toxins). And also agreement in with those recorded by Mahfouz and Sherif (2015), fed Nile tilapia with meals containing $120 \mu \mathrm{g} / \mathrm{kg}$ feed of aflatoxin $\mathrm{B}_{1}$ for twelve weeks. They reported a significant drooping in WG, DG and relative growth rate, but not in the survivability in comparison with the exposure to $20 \mathrm{ppb}$. In despite of the wide difference in growth performance and mortality rates, these may be attributed to the difference in the toxin dose and/or the exposure time.

Our results agree in harmony on the content of what recorded by Ahmed et al., (2020) who concluded that the aflatoxin contaminated feed has a negative impact on the growth and mortality rate of tilapia fingerling which may accelerate the loss of productivity in the aquaculture system. Tuan et al., (2002); Cagauan et al., (2004); Abdelhamid (2008); Selim et al., (2014) and Mahfouz (2015) reported that reduced growth, weight and feed efficacy resulted from exposure to food contaminated with aflatoxin $\mathrm{B}_{1}$ at a low to moderate concentration in a not short period of time. High dose and longtime exposure are mostly responsible for aflatoxin toxicity in tilapia fingerling. The high mortality and haematological changes in Nile tilapia (O. niloticus) are a strong predictor of toxic effects of the $\mathrm{AFB}_{1}$ contaminated diet (Selim et al., 2014). According to Santacroce et al., (2008); Selim et al., (2014) the exposure of fish to $\mathrm{AFB}_{1}$ causes many risks such as the decline in growth performance; increase the chance of disease and high mortality, and cause a negative impact on tilapia WG and feed efficiency over a relatively short period of ten weeks (Zychowski et al., 2013). Likewise Deng et al., (2010) reported, a gradual decrease in growth parameters, occurs when fish are exposed to aflatoxicated diet contaminated with aflatoxin $\mathrm{B}_{1}$.

On the other hand, our study and many other were dis agree with the work carried out by Anater et al., (2020) they found no significant decreases were noted in Daily weight gain (DWG), Body gain (BG) and Feed conversion ratio (FCR), and found significant increases in the standard and overall sizes of silver catfish fed with $180 \mu \mathrm{g} / \mathrm{kg}$ feed. Likewise, we contradict with Huang et al., (2011) and Huang et al., (2014) that did not report any changes in growth of Gibel carp, fed aflatoxicated diet Contain type $\mathrm{B}_{1}$ at rates from 1000 and $2000 \mu \mathrm{g} / \mathrm{kg}$ feed at a period of twelve and twenty four weeks, respectively. This different may be due to they cared out work on different fish species cat fish and (Gibel carp) respectively, indicating that the sensitivity of fish to 
$\mathrm{AFB}_{1}$ difference according to fish species. Anater $\boldsymbol{e t}$ al., (2016) reported that there are factors that play a role in the toxic effects of aflatoxins: dose and type of toxin, type and sex of animal, and duration of exposure to the mycotoxins.

The adverse effect of $\mathrm{AFB}_{1}$ may be attributed to the reasons mentioned by Zhao et al., (2017); Souto et al., (2018); Souza et al., (2020). Where reactive oxygen is produced as a result of stimulation of aflatoxin $\mathrm{B}_{1}$, which causes direct damage to cells and tissues. Marin and Taranu (2012) reported that continuous exposure to aflatoxin pollution causes immune suppression and increase the susceptibility of fish to infectious diseases resulting from deterioration of blood status and overproduction of reactive oxygen species (ROS).

Zinc is an indispensable ingredient element in finfish nutrition (Wei et al., 1999). Adding Zinc in trace amounts has a pivotal role in many vital processes, as it is important for improving growth and regulating enzymes (Halver and Hardy 2002; Jiang et al., 2016; Munir et al., 2020).

In the present study; it has also been observed that $\mathrm{ZnO}$ NPs have a positive impact on the growth and survival rate of studied fish. It was found that the weight gain significantly increased in additives nanoparticles treated fish as compared to the fish kept in control condition, the highest average body weight (63.874 g) was recorded in fish under the $\mathrm{G}_{4}$ ( $\mathrm{ZnO}$ and Hematite) NPs, and $\mathrm{G}_{2}$ which treated with $\mathrm{ZnO} 55.857$ g compare control group which recorded $52.784 \mathrm{~g} \mathrm{~A}$ similar trend was also demonstrated in specific growth rate.

The growth rate, specific growth rate was high in group $\mathrm{G}_{4} 1.473$ while $\mathrm{G}_{2}$ reported 1.319 compared control group which recorded 1.254 Table (1).

The mortality rate was decreased in nanoparticles dietary feed; the survival rate of different groups was significantly different, the highest survival rate was found in $\mathrm{G}_{4}$ which treated with combination of $(\mathrm{ZnO}$ and Hematite) NPs $95.556 \%$, on the other hand $\mathrm{G}_{2}$ was exhibited about $86.667 \%$ of the survival rate similar to that of the control group.

Similarly, these findings were closely similar to those mentioned by Thangapandiyan and Monika (2020) who assured that $10 \mathrm{mg} / \mathrm{kg}$ zinc oxide nanoparticles had improved growth performance, survival rate in Labeo rohita compared with control. Our results are consistent with the findings of Swain et al., (2018) who noticed increase in growth rate in (Labeo rohita) fed diet containing $10 \mathrm{mg} / \mathrm{kg} \mathrm{ZnO}$ NPs. Likewise Jiang et al., (2016); Zhang et al., (2018) noted that adding Zinc in the feed of blunt snout bream promotes the growth such as BW. Liu et al., (2014) found that supplementation the diet with $\mathrm{ZnSO}_{4}$ promoted growth and that adding Zinc at a rate of $184.85 \mathrm{mg} / \mathrm{kg}$ achieved the optimum growth performance for bream. Muralisankar et al., (2015); Asaikkutti et al., (2016) stated that $\mathrm{Zn}, \mathrm{MnO}$, and $\mathrm{Cu}$ NPs supplemented feed produced significant improvements in growth performance, FBW and WG, FCR, beside that controlled the desirable rate of the mortality rate.

Iron is an indispensable mineral element in all animals, as it plays an important role in oxygen transport and cellular respiration (National Research Council 2011).

In the present study; we observed that Hematite nanoparticles have a positive impact on the growth and survival rate of the studied fish. It was found that the weight gain significantly increased in additives nanoparticles treated fish as compared to the fish kept in control condition, the highest average body weight (63.874 g) was recorded in fish under the $\mathrm{G}_{4}$ ( $\mathrm{ZnO}$ and Hematite) and $\mathrm{G}_{3}$ which treated with Hematite $(61.500 \mathrm{~g})$ compared to control group $(52.784 \mathrm{~g})$ a similar trend was also demonstrated specific growth rate.

The growth rate and specific growth rate were high in group $\mathrm{G}_{4}(1.473), \mathrm{G}_{3}$ (1.425) for compared to control group (1.254), Table (1).

The mortality rate was decreased in nanoparticles dietary feed; the survival rate of different groups was significantly different, the highest survival rate was found in $\mathrm{G}_{4}$ which treated with combination of $\mathrm{ZnO}$ and Hematite recording $95.556 \%$ on the other hand $\mathrm{G}_{3}$ was exhibited about $88.889 \%$ of the survival rate.

Our results agree in harmony on the content of what recorded by Shiau and Su (2003) who found a Significant increase in weight and feed conversion efficiency has been reported in juvenile hybrid tilapia when supplementing the diet with iron at a dose of $149 \mathrm{mg} / \mathrm{kg}$. Other studies have reported that dietary iron deficiency could be the cause of decreased growth performance in trials of $O$. niloticus $\mathrm{X} O$. aureus (Hurrell 1997; Lieu et al., 2001; Prentice et al., 2016) and Makwinja and Geremewa (2020) reported that Iron helps in increase growth and prevents anemia in tilapia.

\section{Conclusion}

Nanoparticles of Hematite and Zinc oxide can successfully relieve aflatoxin $B_{1}$ noxious effects in Nile tilapia. 
Table 1. Growth performance and Survival rate of Oreochromis niloticus as affected by the toxicity of aflatoxin and additives of Nanoparticles and their interaction ${ }^{1,2}$.

\begin{tabular}{|c|c|c|c|c|c|c|}
\hline \multirow[b]{2}{*}{ Groups } & \multicolumn{5}{|c|}{ Growth Performance } & \multirow[b]{2}{*}{$\begin{array}{c}\text { Survival rate } \\
(\%)\end{array}$} \\
\hline & $\begin{array}{c}\text { Initial body weight } \\
\left(\mathrm{g} \mathrm{fish}^{-1}\right)\end{array}$ & $\begin{array}{l}\text { Final body weight } \\
\left.\text { (g fish }{ }^{-1}\right)\end{array}$ & $\begin{array}{l}\text { Weight gain } \\
\left.\text { (g fish }{ }^{-1}\right)\end{array}$ & $\begin{array}{c}\text { Daily gain } \\
\left(\mathrm{g} \mathrm{day}^{-1}\right)\end{array}$ & $\begin{array}{c}\text { Specific growth rate } \\
\left(\% \text { day }^{-1}\right)\end{array}$ & \\
\hline $\mathbf{G}_{1}$ & $16.671^{\mathrm{a}}$ & $52.784^{b c}$ & $36.113^{b c}$ & $0.393^{b c}$ & $1.254^{b c}$ & $86.667^{a b c}$ \\
\hline $\mathbf{G}_{2}$ & $16.603^{a}$ & $55.857^{b}$ & $39.255^{b}$ & $0.427^{b}$ & $1.319^{b}$ & $86.667^{a b c}$ \\
\hline $\mathbf{G}_{3}$ & $16.571^{\mathrm{a}}$ & $61.500^{\mathrm{a}}$ & $44.929^{a}$ & $0.488^{a}$ & $1.425^{\mathrm{a}}$ & $88.889^{a b}$ \\
\hline $\mathbf{G}_{4}$ & $16.467^{a}$ & $63.874^{a}$ & $47.407^{a}$ & $0.515^{a}$ & $1.473^{\mathrm{a}}$ & $95.556^{a}$ \\
\hline G5 & $17.005^{\mathrm{a}}$ & $37.856^{e}$ & $20.851^{f}$ & $0.227^{f}$ & $0.868^{e}$ & $57.778^{e}$ \\
\hline G6 & $16.761^{\mathrm{a}}$ & $45.507^{d}$ & $28.746^{e}$ & $0.313^{e}$ & $1.086^{d}$ & $75.556^{d}$ \\
\hline $\mathbf{G}_{7}$ & $16.819^{a}$ & $47.007^{d}$ & $30.188^{\text {de }}$ & $0.328^{\mathrm{de}}$ & $1.117^{d}$ & $77.778^{\mathrm{cd}}$ \\
\hline $\mathbf{G}_{8}$ & $16.680^{\mathrm{a}}$ & $49.762^{\mathrm{cd}}$ & $33.082^{\mathrm{cd}}$ & $0.360^{c d}$ & $1.189^{c d}$ & $84.444^{\mathrm{bcd}}$ \\
\hline Standard error & \pm 0.451 & \pm 1.418 & \pm 1.345 & \pm 0.015 & \pm 0.034 & \pm 3.043 \\
\hline Probability & 0.9939 & 0.0002 & 0.0004 & 0.0004 & $<0.0001$ & $<0.0001$ \\
\hline
\end{tabular}

${ }^{1}$ Values are means of three replicate groups of fish $(\mathrm{n}=3)$.

${ }^{2}$ Values in a column that do not have the same superscript are significantly different according to Duncan's test $(\mathrm{P}<0.05)$.

$\mathrm{G}_{1:}$ Negative control. $\mathrm{G}_{2}$ : treated with Zinc oxide nanoparticles. $\mathrm{G}_{3}$ : treated with Hematite nanoparticles. $\mathrm{G}_{4}$ : treated with combination of Zinc oxide and Hematite nanoparticles. $\mathrm{G}_{5}$ : aflatoxicated group. $\mathrm{G}_{6}$ : aflatoxicated group supplemented with Zinc oxide nanoparticles. $\mathrm{G}_{7}$ : aflatoxicated group supplemented with Hematite oxide nanoparticles. $\mathrm{G}_{8}$ : aflatoxicated group supplemented with combination of Zinc oxide and Hematite nanoparticles.

Table 2. Feed utilization of Oreochromis niloticus as affected by the toxicity of aflatoxin and additives of Nanoparticles and their interaction ${ }^{1,2}$.

$$
\text { Groups }
$$

\begin{tabular}{cc} 
& Feed intake (g/fish) \\
\hline $52.631^{\mathrm{ab}}$ \\
$49.190^{\mathrm{bc}}$ \\
$52.344^{\mathrm{ab}}$ \\
$55.942^{\mathrm{a}}$ \\
$40.278^{\mathrm{e}}$ \\
$44.291^{\mathrm{d}}$ \\
$46.015^{\mathrm{cd}}$ \\
$49.688^{\mathrm{b}}$ \\
\pm 1.168 \\
0.0026
\end{tabular}

\begin{tabular}{c}
\hline Feed intake (g/fish) \\
\hline $52.631^{\mathrm{ab}}$ \\
$49.190^{\mathrm{bc}}$ \\
$52.344^{\mathrm{ab}}$ \\
$55.942^{\mathrm{a}}$ \\
$40.278^{\mathrm{e}}$ \\
$44.291^{\mathrm{d}}$ \\
$46.015^{\mathrm{cd}}$ \\
$49.688^{\mathrm{b}}$ \\
\pm 1.168 \\
0.0026
\end{tabular}

Probability

0.0026

\section{Feed utilization}

Feed conversion ratio

Protein efficiency ratio

$\begin{array}{lc}1.462^{\mathrm{b}} & 2.275^{\mathrm{b}} \\ 1.253^{\mathrm{bc}} & 2.649^{\mathrm{a}} \\ 1.170^{\mathrm{c}} & 2.852^{\mathrm{a}} \\ 1.187^{\mathrm{c}} & 2.812^{\mathrm{a}} \\ 1.950^{\mathrm{a}} & 1.712^{\mathrm{c}} \\ 1.541^{\mathrm{b}} & 2.151^{\mathrm{b}} \\ 1.525^{\mathrm{b}} & 2.175^{\mathrm{b}} \\ 1.502^{\mathrm{b}} & 2.210^{\mathrm{b}} \\ \pm 0.063 & \pm 0.105 \\ <0.0001 & <0.0001\end{array}$

IValues are means of three replicate groups of fish $(\mathrm{n}=3)$.

Values in a column that do not have the same superscript are significantly different according to Duncan's test $(\mathrm{P}<0.05$ ).

作

supplemented with Zinc oxide nanoparticles. $\mathrm{G}_{7}$ : aflatoxicated group supplemented with Hematite oxide nanoparticles. $\mathrm{G}_{8}$ : aflatoxicated group supplemented with combination of Zinc oxide and Hematite nanoparticles. 


\section{References}

Abdel-Daim, M.M.; Dawood, M.A.O.; Aleya, L.; Alkahtanil, S. (2020). Effects of fucoidan on the hematic indicators and antioxidative responses of Nile tilapia (Oreochromis niloticus) fed diets contaminated with aflatoxin $\mathrm{B}_{1}$. Environmental Science and Pollution Research, 27:12579-1258.

Abdelhamid, A.M. (2008). Thirty years (19782008) of mycotoxins research at faculty of agriculture, Almansoura University, Egypt. Engormix. Com, Mycotoxins Technical Articles, pp. 11.

Ahmed, S.; Baten, M.A.; Hossain, M.M.; Rahim, M.M.; Rasul, M.G.; Sultana, R.; Hossain, M.M.; Bapary, M.A.J. (2020). Effects of aflatoxin contaminated feed on the fingerlings of tilapia (Oreochromis niloticus Linnaeus, 1758). Agriculture and Environmental Science, 5(3): 390-396.

Almeida, I.F.M.; Martins, H.M.L.; Santos, S.M.O.; Freitas, M.S.; Costa, J.M.G.; Bernardo, F.M.A. (2011). Mycobiota and Aflatoxin $B_{1}$ in feed for farmed sea bass (Dicentrarchus labrax). Toxins, 3:163-171.

Altunoglu, Y.C.; Bilen, S.; Ulu, F.; Biswas, G. (2017). Immune responses to methanolic extract of black cumin (Nigella sativa) in rainbow trout (Oncorhynchus mykiss). Fish Shellfish Immunol, 67:103-109.

Anater, A.; Araújo, C.M.T.D.; Rocha, D.C.C.; Ostrensky, A.; Filho, J.R.E.; Ribeiro, D.R.; Pimpão, C.T. (2020). Evaluation of growth performance, hematological, biochemical and histopathological parameters of Rhamdia quelen fed with a feed artificially contaminated with aflatoxin $\mathrm{B}_{1}$. Aquaculture Reports, 17: 100326.

Anater, A.; Manyes, L.; Meca, G.; Ferrer, G.; Luciano, F.B.; Pimp ao, C.T.; Font, G. (2016). Mycotoxins and their consequences in aquaculture: A review. Aquaculture, 451, 1-10.

Asaikkutti, A.; mbath, P. (2016). Dietary supplementation of green synthesized manganese oxide nanoparticles and its effect on growth performance, muscle composition and digestive enzyme activities of the giant freshwater prawn Macrobrachium rosenbergii. J Trace Elem Med Biol 35(3):7-17.

Ayyat, M.S; Ayyat, A.M.N.; Al-Sagheer, A.A.; ElHais, A.E.M. (2018). Effect of some safe feed additives on growth performance, blood biochemistry, and bioaccumulation of aflatoxin residues of Nile tilapia fed aflatoxin- $B_{1}$ contaminated diet. Aquaculture 495, 27-34.

Benkerroum, N. (2020). Aflatoxins: ProducingMolds, Structure, Health Issues and Incidence in Southeast Asian and Sub-Saharan African Countries. International Journal of Environmental Research and Public Health, 17(4): 1215.
Cagauan, A.G.; Tayaban, R.H.; Somga, J.R.; Bartolome, R.M. (2004). Effect of aflatoxincontaminated feeds in Nile tilapia (Oreochromis niloticus L.). In Abstract of the 6th international symposium on tilapia in aquaculture (ISTA 6) section: health management and diseases Manila, Philippines (Vol. 12, p. 16).

Daniel, N. (2018). Review on replacing fish meal in aqua feeds using plant protein sources. Int. J. Fish. Aquat. Stud. 6(2), 164-179.

Deng, S.X.; Tian, L.X.; Liu, F.J.; Jin, S.J.; Liang, G.Y.; Yang, H.J.; Du, Z.Y.; Liu, Y.J. (2010). Toxic effects and residue of aflatoxin $\mathrm{B}_{1}$ in tilapia (Oreochromis niloticus 90. aureus) during longterm dietary exposure. Aquaculture 307:233-240.

Duncan, M.B. (1955). Multiple ranges a multiple Ftests. Biometrics, 11:1-42.

Elumalai, P.; Prakash, P.; Musthafa, M.S.; Faggio, C. (2019). Effect of alkoxy glycerol on growth performance, immune response and disease resistance in Nile Tilapia (Oreochromis niloticus). Res Vet Sci 123:298-304.

Halver, J.E.; Hardy, R.W. (2002). Fish Nutrition, third edition. Academic press, New York.

Hassan, A.A.; Mansour, K.; Mahmoud, H.H. (2012). Biosynthesis of silver nanoparticles ( $\mathrm{Ag}-$ NPs) (a model of metals) by Candida albicans and its antifungal activity in some fungal pathogens (Trichophyton mentagrophytes and Candida albicans). Journal of Middle East Applied Science and Technology (JMEAST) 4, 231-239.

Hassan, A.A.; Oraby, N.H.; Mohamed, A.A.E.; Mahmoud, H.H. (2014). The possibility of using Zinc Oxide nanoparticles in controlling some fungal and bacterial strains isolate from buffaloes. Egypt. J. of Appl. Sci., 29, 58-83.

Huang, Y.; Han, D.; Xiao, X.; Zhu, X.; Yang, Y.; Jin, J.; Chen, Y.; Xie, S. (2014). Effect of dietary aflatoxin $\mathrm{B}_{1}$ on growth, fecundity and tissue accumulation in gibel carp during the stage of gonad development Aquaculture, 428-429, pp. 236-242.

Huang, Y.; Han, D.; Zhu, X.M.; Yang, Y.X.; Jin, J.Y.; Chen, Y.F.; Xie, S.Q. (2011). Response and recovery of gibel carp from subchronic oral administration of aflatoxin $\mathrm{B}_{1}$ Aquaculture, 319, pp. 89-97.

Hurrell, R. (1997). Bioavailability of iron. European Journal of Clinical Nutrition, 51 (1997), pp. 4-8.

Jiang, M.; Wu, F.; Huang, F.; Wen, H.; Liu, W.; Tian, J.; Yang, C.; Wang, W. (2016). Effects of dietary $\mathrm{Zn}$ on growth performance, antioxidant responses, and sperm motility of adult blunt snout bream, Megalobrama amblycephala. Aquaculture 464, 121-128

Kenawy, A.M.; El-Genaidy, H.M.; Authman M.M.N.; Abdel-Wahab, M.A. (2009). Pathological studies on effects of aflatoxin on 
Oreochromis niloticus with application of different trials of control. Egypt. J. Comp. Path. Clinic. Path, 22 (1), 175-193.

Lei, Y.P.; Zhou, J.C.; Wang, L.T.; Zheng, W.G.; Zhao, L.H;, Ji, C.A. (2018). Survey report on the mycotoxin contamination of Chinese raw materials and feed in 2017. Feed Ind. 41, 60-64.

Lieu, P.; Heiskala, M.; Petersin, P.; Yang, Y. (2001). The roles of iron in health and dieseases. Molecular Aspect of Medicine, 22, pp. 1-87.

Liu, H.; Ye, Y.; Cai, C.; Wu, T.; Chen, K.; Pu, Q.; (2014). Dietary $\mathrm{Zn}$ requirement of Megalobrama amblycephala. J. Fish. China, 38, 1522-1529.

Mahfouz, M.E. (2015). Ameliorative effect of curcumin on aflatoxin $\mathrm{B}_{1}$ - induced changes in liver gene expression of Oreochromis niloticus. Molekuliarnaia Biologiia, 49, 313-324.

Mahfouz, M.E.; Sherif, A.H. (2015). A multiparameter investigation into adverse effects of aflatoxin on Oreochromis niloticus health status J Basic Appl Zool., 71, pp. 48-59.

Makwinja, R.; Geremewa, A. (2020). Roles and requirements of trace elements in tilapia nutrition: Review. The Egyptian Journal of Aquatic Research, 46(3): 281-287.

Marin, D.E.; Taranu, I. (2012). Overview on aflatoxins and oxidative stress. Toxin Rev, 31:32-43.

Munir, T.; Latif, M.; Mahmood, A.; Malik, A.; Shafiq, F. (2020). Influence of IP-injected $\mathrm{ZnO}$ nanoparticles in Catla catla fish hematological and serological profile. Naunyn-Schmiedeberg's Archives of Pharmacology, 393: 2453-2461.

Muralisankar, T.; Bhavan, P.S; Radhakrishnan, S.; Seenivasan, C.; Srinivasan, V.; Santhanam, P. (2015). Effects of dietary zinc on the growth, digestive enzyme activities, muscle biochemical compositions and antioxidant status of the giant fresh water prawn Macrobrachium rosenbergii. Aquaculture, 448, 98-104.

Nabawy, G.A.; Hassan, A.A.; El-Ahl, R.H.S.; Refai, M. (2014). Effect of metal nanoparticles in comparison with commercial antifungal feed additives on the growth Apergillus Flavus and Aflatoxin $\mathrm{B}_{1}$ prodduction. Jornal of Global Biosciences, 3(6), 954-971.

National Research Council (NRC) (2011). Nutrient requirements of fish and shrimp. Washington: DC: National Academy press.

Oliva-Teles, A.; Enes, P.; Peres, H. (2015). 8Replacing fishmeal and fish oil in industrial aqua feeds for carnivorous fish. Wood head Publishing Series in Food Science, Technology and Nutrition; Davis, D.A.B.T.-F., Ed.; Wood head Publishing: Oxford, UK, pp. 203-233.

Prentice, A.; Mendoza, A.; Pereira, D.; Ceram, C.; Wegmuller, R.; Constable, A.; Spieldenner, J.; (2016). Dietary strategies for improving iron status: Balancing safety and efficacy Nutrition Reviews, 75 (1), pp. 49-60.
Santacroce, M.P.; Conversano, M.C.; Casalino, E.; Lai, O.; Zizzadoro, C.; Centoducati, G.; Crescenzo, G. (2008). Aflatoxins in aquatic species: metabolism, toxicity and perspectives. Rev Fish Biol Fish, 18: 99- 130.

Santos, G.A.; Rodrigues, I.; Starkl, V.; Naehrer, K.; Hofstetter, U. (2010). Mycotoxins in aquaculture: Occurrence in feeds components and impact on animal performance. Av. Nutr. Acuicola, 35, 502-513.

Selim, K.M.; El-Hofy, H.; Khalil, R.H. (2014). The efficacy of three mycotoxins adsorbents to alleviate aflatoxin $\mathrm{B}_{1}$ induced toxicity in Oreochromis niloticus. Aquaculture International, 22, 523-540.

Shiau, S-Y., Su, L-W. (2003). Ferric citrate is half as effective as ferrous sulfate in meeting the iron requirement of juvenile tilapia, oreochromis niloticus x O,aureus. Journal of Nutrition, 133, 483-488.

Souto, N.S.; Braga, C.M.; Freitas, M.L.D.; Fighera, M.R.; Royes, L.F.F.; Oliveira, M.S.; Furian, A.F. (2018). Aflatoxin $B_{1}$ reduces nonenzymatic antioxidant defenses and increases protein kinase $\mathrm{C}$ activation in the cerebral cortex of young rats. Nutr. Neurosci, 21, pp. 268-275.

Souza, C.F.; Baldissera, M.D.; Baldisserotto, B.; Petrollic, T.G.; Glória, E.M.; Zanette, R.A.; Silva, A.S.D. (2020). Dietary vegetable choline improves hepatic health of Nile tilapia (Oreochromis niloticus) fed aflatoxin contaminated diet Comp. Biochem. Physiol. C, 227, Article 108614.

Swain, P.; Das, R.; Das, A.; Padhi, S.K.; Das, K.C.; Mishra, S.S. (2018). Effects of dietary zinc oxide and selenium nanoparticles on growth performance, immune responses and enzyme activity in rohu, Labeo rohita (Hamilton). Aquac Nutr 27(3):1-9.

Thangapandiyan, S.; Monika, S. (2020). Green Synthesized Zinc Oxide Nanoparticles as Feed Additives to Improve Growth, Biochemical, and Hematological Parameters in Freshwater Fish Labeo rohita. Biological Trace Element Research, 195:636-647.

Tuan, N.A.; Grizzle, J.M.; Lovell, R.T.; Manning, B.B.; Roottinghaus, G.E. (2002). Growth and hepatic lesions of Nile tilapia (Oreochromis niloticus) fed diets containing aflatoxin B1. Aquqculture, 212: 311-319.

Umalatha, S.N.; Kushwaha, J.P.; Gangadhar, B. (2016). Digestive enzyme activities in different size groups and segments of the digestive tract in Labeo rohita (Day, 1878). J Aquacult Mar Biol, 4(5):00098.

Wei, W.; Li, A.; Li, D. (1999). Effect of dietary supplemented zinc on the growth and some biochemical parameters of juvenile flounder Paralichthys oliaceus. J.Ocean. Uni Qingado, 18: 60-66. 
Wu, J., Zeng, L.; Li, N.; Liu, C.; Chen, J. (2019). A wash-free and label-free colorimetric biosensor for naked-eye detection of aflatoxin $\mathrm{B}_{1}$ using $\mathrm{G}$ quadruplex as the signal reporter. Volume 298, 125034.

XLSTAT, (2014). Data analysis and statistics with Microsoft Excel, Paris, France.

Zhang, R.; Zhou, Y.; Jiang, X.; Chen, Y.; Wen, C.; Liu, W.; Jiang, Y. (2018). Evaluation of zinc-bearing palygorskite effects on growth performance, nutrient retention, meat quality, and zinc accumulation in blunt snout bream Megalobrama amblycephala. Clay Clay Min. 66, 274-285.
Zhao, W.; Wang, L.; Lium, M.; Jiang, K.Y.; Wang, M.Q.; Yang, G.; Qi, C.C.; Wang, B.J. (2017). Transcriptome, antioxidant enzyme activity and histopathology analysis of hepatopancreas from the white shrimp Litopenaeus vannamei fed with aflatoxin $\mathrm{B}_{1}$ $\left(\mathrm{AFB}_{1}\right)$ Dev.Comp.Immunol., 74: 69-81.

Zychowski, K.E.; Pohlenz, C.; Mays, T.; Romoser, A.; Hume, M.; Buentello, A.; Phillips, T.D. (2013). The effect of NovaSil dietary supplementation on the growth and health performance of Nile tilapia (Oreochromis niloticus) fed aflatoxin-B $\mathrm{B}_{1}$ contaminated feed. Aquaculture, 376: 117-123.

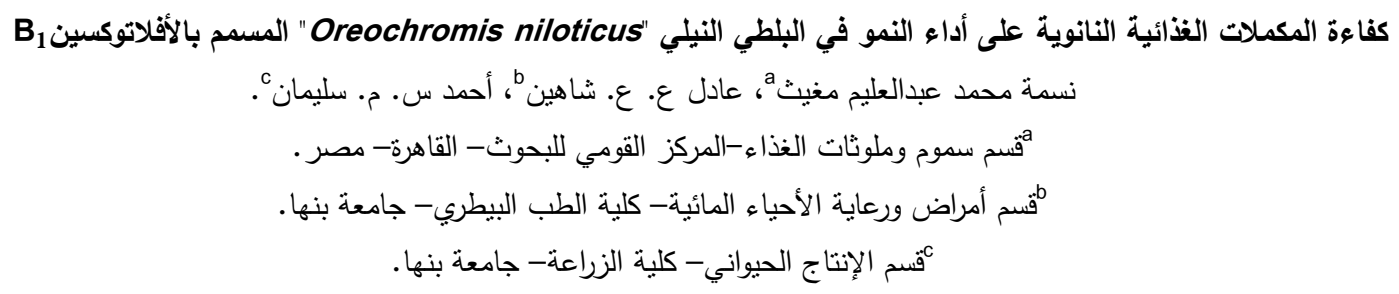

أجريت الدراسة بقسم أمراض ورعاية الأحياء المائية بكلية الطب البيطري جامعة بنها حيث استغرقت فترة زمنية 13 أسبوعاً منذ 1/ يونيو حتى 1/ سبتمبر

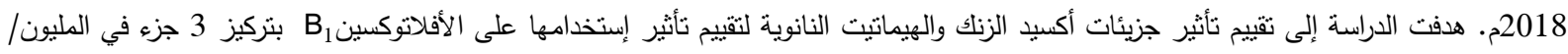

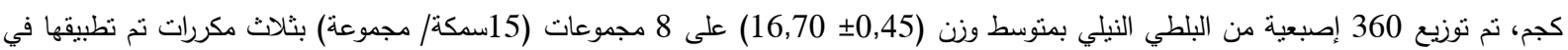
24 حوضاً زجاجياً على النحو الآتي: المجموعة الأولى تتغذيتها على عليقة أساسية كمجموعة حاكمة. بينما تم تغذية المجموعة الثنانبة والمجموعة الثالثة والمجموعة الرابعة على علائق مدعمة

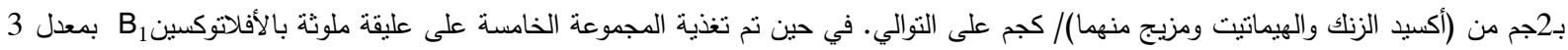
جزء في المليون/ كجم، و تم تغذية المجموعة السادسة والمجموعة السابعة والمجموعة الثامنة على علائق مدعمة بـ2جم من (أكسيد الزنلك والهيماتيت ومزيج

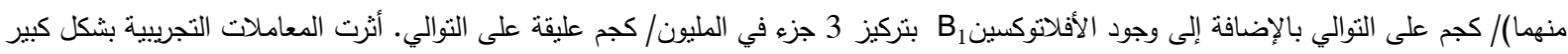

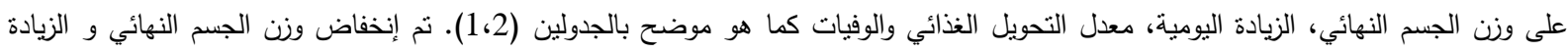

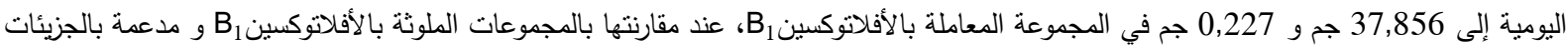
النانوية لأكسيد الزنك، الهيماتيت و مزيج منهما، والتي أبلغت عن وزن الجسم النهائي

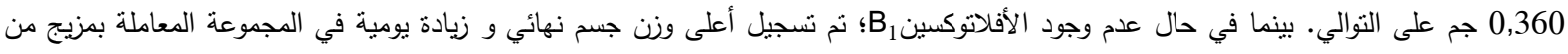

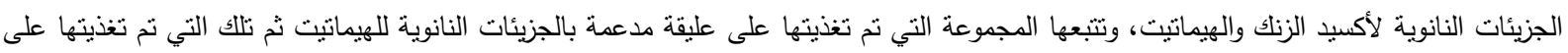

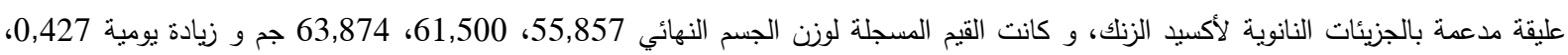
0,488، 0,515 جم على التوالي مقارنةً بالمجموعة الحاكمة التي سجلت وزن جسم نهائي بمقدار

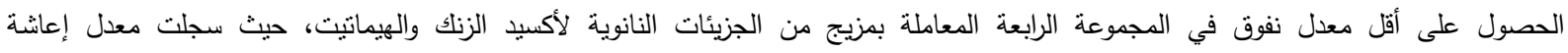

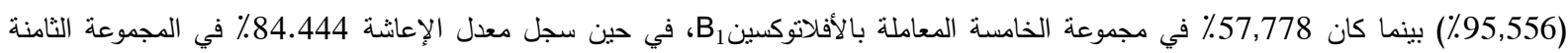

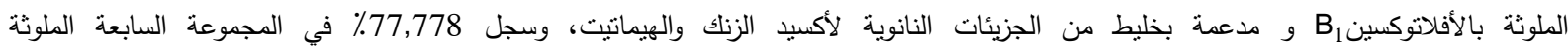

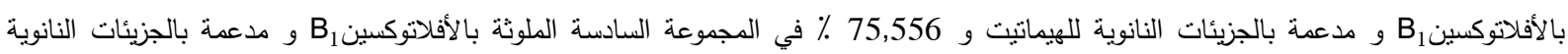

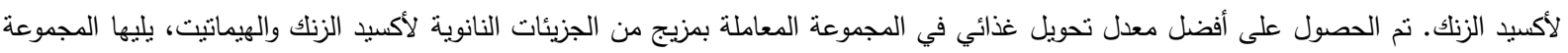

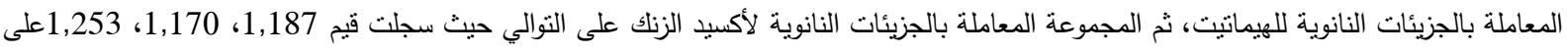

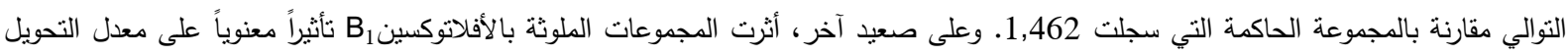

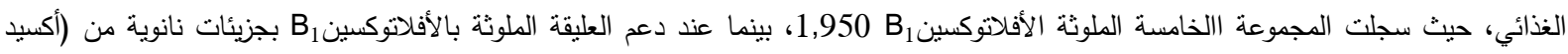

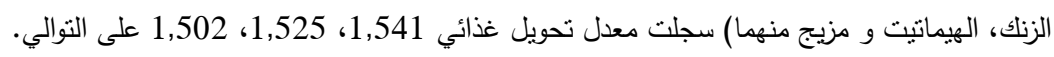
الكلمات الدالة : سلامة الغذاء، الهيماتيت، السموم الفطرية، إضافات الأغذية/الأعلاف النانوية، أكسيد الزنك. 